\title{
China's Internet Finance Boom and Tyrannies of Inclusion
}

Nicholas Loubere

\section{(2) OpenEdition \\ Journals}

Electronic version

URL: http://journals.openedition.org/chinaperspectives/7454

ISSN: 1996-4617

\section{Publisher}

Centre d'étude français sur la Chine contemporaine

\section{Printed version}

Date of publication: 1 December 2017

Number of pages: 9-18

ISSN: 2070-3449

Electronic reference

Nicholas Loubere, «China's Internet Finance Boom and Tyrannies of Inclusion », China Perspectives [Online], 2017/4 | 2017, Online since 01 December 2017, connection on 28 October 2019. URL : http:// journals.openedition.org/chinaperspectives/7454 


\title{
China's Internet Finance Boom
}

\section{and Tyrannies of Inclusion}

\author{
NICHOLAS LOUBERE
}

\begin{abstract}
One of the main drivers of China's e-commerce boom is the dramatic expansion of the country's Internet finance industry, which has grown and diversified at a staggering rate over the past decade. The emergence of Chinese Internet finance has been discussed in largely positive terms as facilitating commercial activity. It has also been linked to the wider developmental goal of promoting financial inclusion through the provision of financial services to previously excluded populations. Emerging from the global microfinance movement, the concept of financial inclusion depicts increased access to financial services (particularly credit) as an inherently beneficial means of empowering the poor and driving bottom-up economic development. This article challenges this dominant narrative of beneficial digital financial inclusion in China. It draws on the growing body of literature critiquing the global financial inclusion movement, and examines examples of exploitation, fraud, instability, and extraction related to expanded digital financial coverage in contemporary China. It then demonstrates that digital financial inclusion is part and parcel of the Chinese government's plans to create a social credit system in an attempt to construct a "trustworthy society." In this way, digital financial inclusion can be seen as a key element in a wider project of expanding surveillance through big data in order to close down spaces for those seeking to contest the hegemonic socioeconomic order. The article argues that these examples illuminate fundamental processes implicit in the expansion of the commercial Internet finance industry. In this way, while the extension of digital financial inclusion in China benefits certain groups, it also necessarily serves to reproduce patterns of inequality and exploitation.
\end{abstract}

KEYWORDS: Internet finance, Digital finance, Financial inclusion, Digital financial inclusion, Microfinance, Microcredit, Social credit, China.

\section{Introduction}

T his article critically examines the sudden emergence and expansion of Internet finance in China. Over the past decade, China's Internet finance industry has grown and diversified at a dizzying rate. Hundreds of millions of people now use third-party online payment services to complete financial transactions, turn to peer-to-peer (P2P) lending platforms or online banks to borrow money, and sidestep brick-and-mortar financial institutions to invest their savings in online investment funds (Guo, Kong, and Wang 2016). This has marked a sea change in how commerce operates in the country, and has transformed the ways in which people access and interact with financial products. Prior to the Internet finance boom, the Chinese financial system was dominated by state-owned institutions operating partially based on political imperatives, rather than unrestrained profit seeking. In China, formal banks are required to lend at below-market interest rates, and have historically targeted larger enterprises and local governments with their loans, making it difficult for households or small businesses to gain access to credit (Ong 2012). The rise of Internet finance has dramatically changed this situation. With the government being slow to issue regulations on the provision of digital financial services, Internet finance providers have had much more freedom to operate than traditional brick-and-mortar financial institutions. This has resulted in vastly expanded coverage to previously excluded groups in both rural and urban areas. In China today, all that is needed to gain access to (semi)formal savings and credit is a smartphone.

China's rapidly evolving Internet finance industry is characterised by diversity and innovation, with a huge number of providers entering the market in an attempt to capitalise on the sudden liberalisation of financial service provision in the country. This has resulted in the development of a wide range of loan and investment products targeting a diverse client baseranging from poor and marginalised rural populations to large urban enterprises in search of investment capital (Guo, Kong, and Wang 2016). Digital loans are primarily provided by two types of Internet finance institutions: online banks and P2P platforms. Online banks-such as WeBank $(30 \%$ owned by Tencent) and MyBank (30\% owned by Ant Financial of the Alibaba Group) - target those involved in e-commerce platforms, including Taobao shop owners and customers, using their online transactions to determine creditworthiness. Currently these banks are only in the business of providing loans, which vary in size from a few thousand to millions of yuan, at rates slightly higher than brick-and-mortar banks. However their ultimate goal is to become full deposit-taking financial institutions. ${ }^{(1)}$ China's P2P market is the world's largest, with almost 6,000 P2P platforms facilitating transactions worth approximately one trillion yuan in 2016. Some large platforms, such as Paipaidai, serve more than two million active borrowers and lenders. (2) P2P platforms are theoretically only supposed to act as intermediaries, providing a service allowing lenders to offer credit directly to borrowers. However, in reality a wide range of P2P platforms operate in very different ways. In some cases platforms pool lender funds and engage in asset transformation, thus creating a space between the lender and the bor-

1. Josh Horwitz, "Alibaba's Customers Can Now Get a Loan Based on Their Online Shopping History," Quartz, 25 June 2015, https://qz.com/436889/alibabas-customers-can-now-get-a-loan-basedon-their-online-shopping-history/ (accessed on 2 November 2017); "Banking and Finance in China: The Outlook for 2015," PWC, February 2015, https://www.pwchk.com/en/industries/financialservices/publications/banking-and-finance-in-china-the-outlook-for-2015.html (accessed on 2 November 2017).

2. For up-to-date information on the Chinese P2P industry, as well as individual platforms, visit: http://shuju.wdzj.com/industry-list.html (accessed on 2 November 2017). 
rower (Deer, Mi, and Yu 2015). These types of practices have resulted in fraudulent activity and some high-profile bankruptcies (see section four), and have prompted a regulatory crackdown. ${ }^{(3)}$ While this has restricted the behaviour of P2P platforms and somewhat consolidated the industry, space still remains for disruptive (or chaotic) innovation.

P2P platforms must be understood as vehicles for both credit and investment, as lenders use P2P services as an alternative to parking their capital in low-interest savings accounts. While engaging in P2P lending can be a relatively risky activity, it offers substantially higher returns than traditional types of investment. Moreover, some P2P platforms provide the option of fixed returns over a specific period of time, mimicking investment products offered by brick-and-mortar financial institutions, and giving the illusion of security. ${ }^{(4)}$ Nevertheless, the recent collapse of large P2P platforms has negatively affected the industry's reputation, and industry trackers estimate that at least one-third of platforms have financial problems or engage in fraudulent activity (Jingu 2016). This has prompted would-be investors to look elsewhere.

Online investment funds offered by China's Internet giants are another option for those too risk-averse to enter the P2P market. These online funds permit investors to transfer any amount of money into their accounts, which is then invested directly in the interbank market, providing relatively high returns. For instance, Ant Financial's Yu'ebao offers an annual interest rate of close to $4 \%$, compared with only $0.35 \%$ provided by most traditional banks. Investors can also withdraw the money whenever they want, and even use their accounts to settle online transactions. This situation has resulted in online investment funds vacuuming up huge amounts of savings that would have previously been deposited in brick-and-mortar financial institutions, and has made Yu'ebao the world's largest investment fund, managing over US\$165 billion from more than 260 million investors. ${ }^{(5)}$ This represents a challenge to traditional banking, and has prompted some brick-and-mortar financial institutions to respond by developing their own online investment products. ${ }^{(6)}$

The reaction to China's Internet finance boom has been largely uncritical and depicted in positive terms. Indeed, many of the discussions in academic, media, and policy circles have characterised the rapid diversification and expansion of digital financial services as providing much-needed access to credit, and pushing traditional banks to improve their services through competition-both of which are seen as contributing positively to the country's development (Arner, Barberis, and Buckley 2015). ${ }^{(7)}$ This mirrors the discourse of the global financial inclusion movement, which promotes the expansion of access to financial services as a strategy to empower marginal populations and drive bottom-up socioeconomic development (Sparreboom and Duflos 2012; World Bank 2014). (8) Proponents of financial inclusion depict fraud and abuses associated with digital finance as growing pains for a rapidly expanding industry-unfortunate outcomes that can be remedied with proper regulation and technocratic fixes, rather than fundamental features of a commercially-oriented Internet financial system. These negative outcomes are also seen as a small price to pay in order to allow China's digital financial sphere to continue innovating, with one commentator even going so far as to say:

\section{Chinese innovations like printing, gunpowder and the magnet spread worldwide and fundamentally changed the world as it then was. Sim- ilarly, the ripples from the current golden era of internet finance are likely to be felt well beyond China's borders. (9)}

Implied in statements like this is the idea that China is at the vanguard of Internet financial innovation that will shape the world for the good. How- ever, the seemingly inadvertent use of gunpowder in this metaphor-an innovation that undoubtedly has had tyrannous results - also points to the potential dark sides of this innovation.

This article examines the dark manifestations of China's digital financial innovation and expansion. This is accomplished through an analysis of some of the discontents and tyrannies that have arisen from the rapid expansion of digital financial inclusion in contemporary China. It is important to note at the outset that the analysis in this article does not draw on primary empirical data. Rather, it seeks to extend a conceptual critique of the discourse and practice of digital financial inclusion in China by bringing theoretically informed critical perspectives to bear on recent high-profile instances of exploitation, fraud, and the expansion of the Chinese surveillance state. The rest of the article is organised as follows: the next section outlines the development and goals of the global financial inclusion movement, and highlights a number of normative claims that have been made about the benefits associated with expanding access to financial services. Sections three, four, and five detail three examples of how digital financial inclusion can manifest in tyrannous ways, having negative consequences for the newly included and potentially impacting the wider society and economy in adverse ways. Section six concludes the paper by reflecting on the patterns of inequality and exploitation that are reproduced through processes of inclusion, and identifying some important areas for future research.

\section{The promise of financial inclusion}

The idea that inclusion into the formal financial system is inherently beneficial derives from, and overlaps with, the rapid expansion and popularisation of the global microfinance movement over the past half-century. Modern microlending began with US-funded development programmes in Latin America in the 1960s, primarily aimed at stymying leftist uprisings. However, popular microfinance mythology places the movement's origins in Muhammad Yunus' experiments with lending to the poor in rural Bangladesh, and the establishment of the Grameen Bank in 1983 (Bateman 2015; Yunus and Weber 2007). Throughout the 1980s, Grameen and other

3. China Banking Regulatory Commission, Ministry of Industry and Information Technology, Public Security Bureau, and China Internet Information Technology Office, "Wangluo jiedai xinxi zhongjie jigou yewu huodong guanli zhanxing banfa" (Interim measures for the management of the business activities of Internet lending intermediaries), 17 August 2016, http://www.miit.gov.cn/ n1146295/n1146557/n1146624/c5218617/content.html (accessed on 2 November 2017).

4. "Banking and Finance in China:The Outlook for 2015," PWC, February 2015, op cit;: Gabriel Wildau, "China Curbs 'WildWest' P2P Loan Sector," Financial Times, 5 April 2017, https://www.ft.com/content/b0e40438-fda7-11e6-8d8e-a5e3738f9ae4 (accessed on 2 November 2017).

5. Guo Jia, "Alibaba's Yu'e Bao Becomes World's Largest Money Market Fund," SupChina (blog), 28 April 2017, http://supchina.com/2017/04/28/alibabas-yue-bao-becomes-worlds-largest-moneymarket-fund-china-business-technology-news-april-28-2017/ (accessed on 2 November 2017).

6. "Banking and Finance in China: The Outlook for 2015," PWC, 2015, op. cit.

7. Peter Cai, "Alibaba's Yuebao Gives China's Banks a Rude Awakening," The Australian, 6 March 2014, http://at.theaustralian.com.au/link/2b13e82b935177db02bf2af0e1ff7723?domain=theaustralian.com.au (accessed on 2 November 2017); China Banking Regulatory Commission, Ministry of Industry and Information Technology, Public Security Bureau, and China Internet Information Technology Office, "Wangluo jiedai xinxi zhongjie jigou yewu huodong guanli zhanxing banfa" (Interim measures for the management of the business activities of Internet lending intermediaries), 2016, op. cit.

8. Bai Chengyu, "The Origin and Role of Inclusive Finance in China," China Development Gateway (blog), 6 June 2016, http://en.chinagate.cn/2016-06/06/content_38610696.htm (accessed on 2 November 2017).

9. David Porteous, "The 'Colden Age' of Digital Finance in China," Digital Frontiers Institute (blog), 9 February 2017, https://digitalfrontiersinstitute.org/switch/component/easyblog/entry/ 2017/02/the-golden-age-of-digital-finance-in-china?!temid=thought-leadership (accessed on 2 November 2017) 
microfinance institutions adopted a poverty lending approach aimed at providing small, subsidised loans to poor, unbanked populations though jointliability loan groups rather than requiring collateral. Because the loans were offered at below market rates, these initial microfinance providers were not financially sustainable, and instead depended on the patronage of funders (Morduch 2008). This all changed in the 1990s through a concerted effortled by the World Bank, USAID, and other pillars of the global neoliberal establishment-to push microfinance institutions to operate at "full cost recovery" (Bateman 2015, p. 6). Proponents of this new financial systems approach argued that microfinance providers should abandon subsidised interest rates, and adopt commercial best practices. This would provide the basis for sustainability (and even profitability), allowing them to scale-up their operations and expand the benefits of microfinance to more people (Robinson 2008; Rutherford 2006).

The widespread adoption of the financial systems approach, and the subsequent transformation of microfinance into a commercially-oriented activity, laid the foundations for the rapid growth of the industry. With high-profile backing and funding from development institutions-such as the International Monetary Fund (IMF), the World Bank, and the Bill and Melinda Gates Foundation-microfinance became the best funded and most popular development intervention of all time (Bateman 2010). The IMF in particular found microfinance to be a useful tool to soften the edges of its Structural Adjustment Programmes (i.e. austerity measures) imposed on low-income countries in need of financial assistance (Weber 2004). Microfinance became seen as a win-win proposition, as it supposedly helped the poor while simultaneously generating profit-making opportunities for investors. The developmental capabilities of microfinance were expressed in hyperbolic terms, with Yunus himself claiming that it would contribute to putting poverty in a museum within a few decades (Yunus and Weber 2007). By the 2000s, microfinance was the global development strategy par excellence, leading the United Nations to declare 2005 the International Year of Microcredit. One year later, Yunus and the Grameen Bank were the recipients of the Nobel Peace Prize, and President Barack Obama awarded Yunus the Presidential Medal of Freedom in 2009. ${ }^{(10)}$

However, in the mid to late 2000s microfinance came under increasing scrutiny and critique, with a number of studies finding no evidence for the claims of poverty reduction, and some research highlighting the ways in which microcredit could actually hurt borrowers and undermine development (Bateman 2010; Duvendack et al. 2011; Guérin, Morvant-Roux, and Villarreal 2014; Guérin, Labie, and Servet 2015; Mader and Sabrow 2015). The microfinance industry's reputation was further damaged by a massive microfinance crisis in Andhra Pradesh, India, resulting in over-indebted borrowers committing suicide (Taylor 2011). This prompted a recalibration and rebranding of the microfinance industry, shifting the goal from actively reducing poverty through small loans, to focusing on financial inclusion, with the expansion of access to financial services being depicted as a beneficial outcome in and of itself. Like microfinance before it, the discourse of financial inclusion received the full support of the major neoliberal development institutions, as well as large financial multinationals such as MasterCard and Citibank. By 2014 financial inclusion had taken up the mantel of microfinance, and was the main focus of the World Bank's 2014 Global Financial Development Report, which stated: "Financial inclusion represents a core topic, given its implications for reducing poverty and boosting shared prosperity" (World Bank 2014, p. xi). The shift to the promotion of financial inclusion signalled the full embrace of a profit-oriented approach to devel- opmental finance. This was justified as creating the conditions necessary to allow commercial financial institutions to scale-up their businesses and reach more clients. These goals are made clear in a report released by the Consultative Group to Assist the Poor (CGAP), in which Elizabeth Littlefield (CEO of the CGAP) stated (Helms 2006, p. 5):

We have helped push microfinance beyond the conference rooms of aid agencies, to the boardrooms of commercial bankers and policymakers (...) the picture so far is breathtaking. Where small, heavily subsidized microcredit schemes used to be the norm, hundreds of profitable microfinance providers of all institutional shapes and forms are now offering a wide range of financial services.

This long journey from the provision of small subsidised microcredit to a concerted global campaign to extend access to commercial financial services to every person in the world may seem like mission drift, but it is premised on one core assumption: That inclusion into the formal financial system is inherently beneficial. This assumption is based on the observation that "there is a direct correlation between financial exclusion and poverty" (IFAD 2001, p. 8). By extension, therefore, inclusion is seen as correlating with the opposite of poverty-prosperity. Proponents of financial inclusion concede that expanding the provision of commercial financial services "at all costs" may have immediate negative effects and "can actually exacerbate financial and economic instability" (World Bank 2014, p. xi). However, suboptimal outcomes are blamed on the failure to follow best practice, and are therefore depicted as exceptional results that can be remedied with technocratic fixes. Digital technologies are seen as one of the key ways to reduce these risks by "increasing financial security" (World Bank 2014, p. 3), and Internet finance is at the core of the financial inclusion agenda. According to the Global Partnership for Financial Inclusion (GPFI):

As one of the greatest innovations that has facilitated financial inclusion in this decade, digital finance, including mobile payments, Internet banking, P2P lending, online insurance, crowdfunding etc., has successfully improved access to finance by the poor, the elderly, the young, women, farmers, SMEs and other under-served groups. (11)

As Philip Mader points out, the financial inclusion strategy is not based on concrete evidence of its ability to achieve specific developmental outcomes, e.g. poverty reduction (Mader 2016b). Rather, it is based on the unlocking of developmental potential by providing the unbanked with new opportunities. In particular, the discourse of beneficial financial inclusion is rooted in three promises. The first promise is that inclusion into the formal financial system is empowering for the unbanked, allowing them to pull themselves up by their own bootstraps. In the words of the CGAP (Helms 2006, p. xi):

We have seen the cascading power of microfinance. We have seen how access to loans and deposit services has empowered millions of people to work their way out of poverty.

10. Thomas Frank, "Nor a Lender Be," Harper's Magazine, 19 February 2016, https://harpers.org/blog/ 2016/02/nor-a-lender-be/ (accessed 2 November 2017)

11. "China 2016 Priorities Paper," Global Partnership for Financial Inclusion, 2016, http://www.gpfi.org/publications/global-partnership-financial-inclusion-gpfi-china-2016-priorities-paper (accessed 2 November 2017). 
The second promise is that this empowerment also serves to generate more freedom by democratising access to financial services and liberating the marginal from an excluded existence. Indeed, Yunus has frequently referred to financial exclusion as "financial apartheid," and has called credit a basic human right, thereby equating the lack of access to formal financial services with systems of racism and oppression (Mader 2015; Yunus and Weber 2007, p. 49). The third promise is that widening access to financial services drives broader economic growth through bottom-up development, which has beneficial knock-on effects for society as a whole. In the words of Yunus (Yunus and Weber 2007, p. 56):

Microcredit turns on the economic engines among the rejected population of society. Once a large number of these tiny engines start working, the stage is set for big things.

Financial inclusion has also become a key development strategy in China. Microfinance gained popularity as a development intervention in the country in the 1990s, with the establishment of a number of microfinance NGOs and the incorporation of microcredit into the government's development strategies. While China's NGO microfinance sector remained small compared to other countries - primarily due to regulations restricting the provision of financial services by NGOs-government-run microcredit programmes aimed at providing loans for poverty reduction, farmers, and laid-off workers expanded rapidly (Park and Ren 2001; Tsai 2004). In the early 2000s, the Chinese government initiated a programme mandating that all rural credit cooperatives (over 30,000 branches in total) must use at least $60 \%$ of their lending capital for subsidised microcredit, making it one of the largest microcredit initiatives in the world (Loubere 2016). In 2005, the China Association of Microfinance (CAM) was established in the Chinese Academy of Social Sciences (CASS) with funding support from Citibank and other multinational commercial financial institutions. CAM and other advocates of microfinance in China identified the widespread use of informal financial services in poor rural areas as undermining development efforts, and lobbied for de-regulation in order to allow commercial financial institutions to enter the rural market (Sparreboom and Duflos 2012). In particular, microfinance proponents pushed for the liberalisation of interest rates and privatisation of land rights for use as collateral (OECD 2003). In 2006 and 2007, this lobbying partially paid off with the legalisation of two new types of financial institution-Village and Township Banks (VTBs) and Microloan Companies (MLCs) — which were allowed to lend at higher interest rates. This move effectively opened up the rural financial sector to commercial banking, with major global banks such as HSBC and Citibank establishing branches around the country (Loubere and Zhang 2015). The term financial inclusion was imported into China in 2005 after its popularisation globally. It was translated from World Bank documents by Bai Chengyu (Secretary General of CAM) as puhui jinrong (普惠金融). Bai suggests that the Chinese translation actually refers to "inclusive finance," which implies a focus on the wider system, rather than on providers or services. This is perhaps meant to leave the door open for a larger governmental role in coordinating the inclusive financial system. China's Internet finance boom has also been incorporated into financial inclusion strategies. In the words of Bai:

Inclusive finance and Internet finance have a lot in common, being open, inclusive and equal. Internet finance reaches the bottom of the financial sector, and heightens financial inclusion, while financial inclusion serves as policy guidance for Internet-based financing. ${ }^{(12)}$

The discourse of financial inclusion has been explicitly linked to the Chinese government's other developmental agendas. In 2015, the State Council issued the first national strategic plan to promote financial inclusion, which was approved by the Central Leading Group for Comprehensively Deepening Reforms (chaired by Xi Jinping). The document identifies financial inclusion as a key element in the realisation of a "moderately prosperous society" (xiaokang shehui 小康社会) and commits to letting market forces lead with governmental guidance. It also connects Internet finance to the inclusive finance agenda, highlighting the importance of "improving the application of technology in financial institutions (...) [and] leveraging the internet to promote the development of financial inclusion." (13) The government's 2017 Number One Document (yihao wenjian一号文件) also emphasises the importance of expanding digital financial inclusion for the promotion of rural development:

We should encourage the active use of Internet technology by financial institutions in order to offer micro-deposits, microloans, payments, settlements, insurance, and other types of financial services to agricultural producers. ${ }^{(14)}$

While much has been made of the regulatory crackdown on Internet finance providers in 2016, it is worth pointing out that the policies have still been largely supportive, and have left plenty of room for the continued development of the industry. ${ }^{(15)}$ The Chinese government has signalled its support for the digital financial inclusion agenda in other ways as well. For instance, Premier Li Keqiang attended the launch of Tencent's WeBank, reportedly saying that the development of Internet banking "will lower costs for and deliver practical benefits to small clients, while forcing traditional financial institutions to accelerate reforms." (16)

With this high-level encouragement, Internet finance companies have been quick to incorporate the language and symbolism of financial inclusion into their marketing strategies, thus framing their commercial activities as being widely beneficial to society. For instance, Ant Financial's website states:

With the help of Big Data, cloud computing and other technologies, users can enjoy equal access to financial services. This greatly expands the scope of inclusive financial services. ${ }^{(17)}$

12. Bai Chengyu, "The Origin and Role of Inclusive Finance in China," op. cit.

13. State Council, "Guowuyuan guanyu yinfa tuijin puhui jirong fazhan guihu (2016-2020 nian) de tongzhi" (The State Council on the publication and promotion of plan for the development of financial inclusion 2016-2020), 31 December 2015, http://www.gov.cn/zhengce/content/201601/15/content_10602.htm (accessed 2 November 2017).

14. State Council, "Guowuyuan guanyu shenru tuijin nongye gongjice jiegou xing gaige jiakuai peiyu nongye nongcun fazhan xin dongneng de ruogan yijian" (Opinions on deepening the promotion of supply side structural agriculture reform to accelerate the cultivation new energy for rural development), 31 December 2016, http://news.xinhuanet.com/politics/2017-02/05/c_112 0413568.htm (accessed on 2 November 2017).

15. China Banking Regulatory Commission, Ministry of Industry and Information Technology, Public Security Bureau, and China Internet Information Technology Office, "Wangluo jiedai xinxi zhongjie jigou yewu huodong guanli zhanxing banfa" (Interim measures for the management of the business activities of Internet lending intermediaries), 2016, op. cit.

16. "Banking and Finance in China: The Outlook for 2015," PWC, 2015, op. cit., p. 38

17. See the homepage of Ant Financial: https://www.antfin.com/brand.htm (accessed on 2 November 2017). 
It also displays a series of photographs, each with its own story, showing the different kinds of people who benefit from the expanded access to financial services offered by the company-including entrepreneurs, travellers, farmers, freelancers, and recent university graduates. CreditEase-one of the largest P2P companies in the country-also characterises its activities as financial inclusion on its website, and even incorporates the Chinese term for inclusive finance into its name-yixin puhui (宜信普惠). ${ }^{(18)}$

\section{Inclusive lending and (dis)empowerment}

While the discussions surrounding China's booming Internet finance industry and the associated expansion of digital financial inclusion have been largely framed in positive terms, there have also been a number of highprofile examples of negative outcomes related to the increased access to financial services. One of the most visible discontents in recent years was the eruption of the "naked borrowing" (luotiao jiedai 裸条借贷) scandal in the summer of 2016. In June, media outlets in China and abroad reported that female university students were being required to provide nude photos of themselves, along with the contact details of friends and family members, as collateral for loans at high interest borrowed through the widely used P2P platform Jiedaibao. ${ }^{(19)}$ When the students were unable to repay, they were forced to take out additional loans at even more usurious rates. If they did not comply, the lenders threatened to publish the photos online and send them to their social/familial networks. Additional reporting on the subject revealed that this practice was not restricted to Jiedaibao, but was widespread across a number of other P2P platforms. The digital loan sharks were actually middlemen who raised money from a number of different sources before on-lending to desperate students (Loubere 2017). (20) Shockingly, at the time of writing the use of naked photos to secure online loans was not even illegal, as long as the naked pictures were not actually shared. While this is undoubtedly an extreme example of the exploitative potential of digital financial inclusion, it also sheds light on the lack of regulatory protections for consumers. Indeed, recent regulations do not specify what can and cannot be used to guarantee loans, instead leaving it up to individual platforms to find "innovative" ways to reduce risk. (21)

Once trapped in a cycle of debt and threatened with the public exposure of naked images, the students are powerless at the hands of the digital loan sharks-transformed into subordinated subjects primed for exploitation. This has resulted in some girls being pushed into prostitution, either with the loan sharks themselves or being marketed as mistresses for hire. ${ }^{(22)} \mathrm{A}$ number of students have also committed suicide or gone missing due to the inescapable debt, with others talking about receiving threats from debt collection companies hired by lending platforms to retrieve their money. ${ }^{(23)}$ The government has since outlawed online loans to students and instructed state-owned banks to resume campus lending at subsidised rates-a practice that had been halted for the past 18 years. ${ }^{(24)}$ As mentioned above, the government has also promulgated sweeping new regulations aimed at controlling these blatant abuses. However, they have left plenty of grey areas open, allowing space for those with enough entrepreneurial spirit to continue identifying new ways to make profit and push forward the development of the Internet finance industry (Loubere 2017).

The ban may reduce high-profile stories about university students falling victim to digital loan sharks in the future. However, it will not put an end to the issue at the heart of the scandal: i.e., in order to provide credit to marginal people who represent a risk for repayment, borrowers whose op- erations are based on profit-maximising principles will seek ways to ensure repayment, or extract something of similar (or greater) value from their debtors in the case of default. For this reason, this example represents a fundamental flaw in the beneficial financial inclusion narrative. The "naked borrowing" scandal is undoubtedly a story of increased inclusion, as prior to the rapid expansion of the P2P industry college students were barred from getting loans from formal banks. It is also a story of empowermentjust not for the formerly excluded students, but rather for their creditors. Indeed, one of the real beneficiaries of a more inclusive financial system is the entrepreneurial digital loan shark whose ability to participate is due to liberalisation of the financial sphere in China. Therefore, these newly included digital lenders must be understood as navigating the expanding frontiers of financial inclusion-in this case transforming debt into new levers of control in order to literally gain power over the bodies of their debtors. This example contradicts the myth of financial inclusion as a great equaliser, showing instead that inclusion tends to reproduce and strengthen unequal relations of power, rather than reduce them (Taylor 2012).

\section{Inclusive (anti)development}

Inclusion into the rapidly evolving world of Internet finance also represents a variety of other risks for consumers and the economy more broadly. It is estimated that approximately one-third of P2P lenders are in financial trouble, and since 2011 thousands of P2P platforms have gone bust, many due to fraudulent practices (Jingu 2016). ${ }^{(25)}$ Some of these were extremely large operations — such as Ezubao, which had pulled in over 70 billion yuan from nearly one million individuals who had invested money under the illusion that it would be on-lent to borrowers providing high returns. In reality, the founder of Ezubao embezzled much of the money for personal use. When the platform went bankrupt, it was these investors who lost their money. P2P platforms like Ezubao have been successful at attracting investors for a couple of reasons. Firstly, they promise interest rates much higher than

18. See the homepage of CreditEase: http://www.yixin.com (accessed on 2 November 2017).

19. '"Luotiao' jiedai jingxian daxuesheng qunti, bu huan qian bei weixie gongbu luozhao" (Shocking news about 'naked borrowing' amongst university students, with threats of publishing the naked photos if loans are not repaid), Southern Metropolis Daily, 13 June 2016, http://m.mp.oeeee. com/a/BAAFRD0000201606136604.html (accessed on 2 November 2017).

20. Nathan Jubb, "Desperate Students Secure Loans With Naked Photos," Sixth Tone, 14 June 2016, http://www.sixthtone.com/news/desperate-students-secure-loans-naked-photos. (accessed on 2 November 2017); Stuart Leavenworth, "China's 'Naked Loans' Force Female Students to Bare All in Return for More Cash," The Guardian, 15 June 2016, https://www.theguardian.com/world/ 2016/jun/15/chinas-naked-loans-force-female-students-to-bare-all-in-return-for-more-cash (accessed on 2 November 2017).

21. China Banking Regulatory Commission, Ministry of Industry and Information Technology, Public Security Bureau, and China Internet Information Technology Office, "Wangluo jiedai xinxi zhongjie jigou yewu huodong guanli zhanxing banfa" (Interim Measures for the Management of the Business Activities of Internet Lending Intermediaries), 2016, op. cit:; People's Bank of China, "Guanyu cujin hulianwang jinrong jiankang fazhan de zhidao yijian" (Guiding Opinions on Promoting the Healthy Development of Internet Finance), 2015, op. cit

22. Guo Yiming, "College Girls Fall Prey to 'Naked Loan,'" China.org.cn (blog), 1 October 2016, http://www.china.org.cn/china/2016-10/01/content_39408034.htm (accessed on 2 November 2017).

23. Dong Heng, "Online Lenders Seduce College Kids," Sixth Tone, 21 April 2016, http://www.sixthtone.com/news/762/loan-need-trap-indeed (accessed on 2 November 2017); Liang Chenyu "Student With $\$ 49,000$ Debt Leaves Farewell Note, Goes Missing," Sixth Tone, 12 May 2017, http://www.sixthtone.com/news/1000190/student-with-\%2449\%2C000-debt-leaves-farewellnote\%2C-goes-missing (accessed on 2 November 2017).

24. "China Bans Online Loans to College Students," China Daily, 20 June 2017, http://www. chinadaily.com.cn/china/2017-06/20/content_29811721.htm (accessed on 2 November 2017).

25. Gabriel Wildau, "China Curbs 'Wild West' P2P Loan Sector," Financial Times, 5 April 2017, https://www.ft.com/content/b0e40438-fda7-11e6-8d8e-a5e3738f9ae4 (accessed on 2 November 2017). 
those offered by brick-and-mortar financial institutions. Secondly, many investors seem to equate the P2P platforms with the implicitly state-guaranteed formal financial sector, and do not fully realise the risks involved. Ezubao recognised this, going to great lengths to cloak itself in the symbolism and legitimacy of the state. The company advertised on CCTV, used official-sounding language on its website, and even hosted its annual meeting at the Great Hall of the People in 2015 (Albrecht et al. 2017; Loubere 2017). (26) Ezubao's collapse therefore came as a shock to many who had assumed that the company had the backing and support of the government in the same way as brick-and-mortar financial institutions.

This type of scam is not only a threat to the newly included individual consumers who were victims of the fraudulent investment operation. It also represents a threat to wider financial stability, as the new regulations have required Internet lending platforms to store their funds in officially registered banks, thus pushing them to become more fully integrated into the formal financial sector. Moreover, P2P lenders are increasingly establishing partnerships with banks and integrating their platforms into bank business activities (Deer, Mi, and Yu 2015; Loubere 2017). While this formalisation of the P2P sector will undoubtedly curb some of the more audacious examples of fraud, the ability of P2P lenders to generate higher profits will also surely pressure traditional financial institutions into adopting new-often more risky-behaviours. Past financial crises have shown that it is the poor and more vulnerable members of society who are disproportionately affected by the kinds of boom-bust cycles associated with the rapid expansion of under-regulated and aggressively profit-oriented lending. In particular, examples from collapses in the Indian and South African microfinance industries point to the potential for financial inclusion initiatives to quickly become giant bubbles fuelled by sub-prime lending, with terrible results for those at the bottom of the pyramid (Bateman 2014; Mader 2015; Taylor 2011).

While these high-profile examples of fraud represent the illegal extraction and theft of investor resources, the expansion of the Internet finance industry also gives rise to legally sanctioned forms of resource extraction from marginal areas and people. Indeed, the commercial financial sector is generally in the business of attracting resources and allocating them to the "most productive" places for investment. These havens of productivity are mostly located in prosperous areas with well-developed infrastructure and secure investment opportunities for the select few. Therefore, widening the reach of the commercially-oriented Internet finance system to more marginal areas and people allows for the financialisation and extraction of their limited resources for use as investment capital in non-marginal places. This represents a subtle form of accumulation by dispossession built into the financial system itself (Harvey 2007; James 2014).

While these underlying extractive processes had already been exacerbated through the liberalisation and commercialisation of China's brick-and-mortar financial institutions over the past decade (Loubere and Zhang 2015), they have been dramatically accelerated by the unabashed profit orientation of those participating in the Internet finance boom. For instance, research has illustrated that electronic payment systems — such as Alipay and WeChat Pay-facilitate transfers of wealth from the poor to rich segments of society through accumulative processes (Mader 2016b). The predominance of these private third-party payment systems in the Chinese market-making up $60 \%$ of all online payments-also cuts into the profit of formal (primarily state-owned) banks, as they receive only a fraction of the transaction fee. (27)

Additionally, the state-dominated formal financial sector is being challenged by the myriad online investment funds being offered by Internet gi- ants such as Alibaba's Yu'ebao. (28) These funds provide higher interest than the capped rates of state-owned banks. They are also liquid, allowing investors to withdraw money at any time and even to use their funds to make online payments. ${ }^{(29)}$ They have therefore attracted huge amounts of capital that would have previously been saved in state-owned banks and used as financing for investment projects, often in state-owned enterprises. Many commentators believe this represents a necessary disruption, as they perceive the stranglehold of the Chinese state-owned banks on the financial system as undermining the country's development (Ong 2012). They argue that the success of China's Internet finance providers "shows what Chinese entrepreneurs are capable of once the government gets out of their way." (30) However, China's economic miracle in the 1980s and 1990s cannot be attributed only to the release of the Chinese people's entrepreneurial spirit. Rather, it was largely the result of banks and credit cooperatives funnelling investment into state-owned enterprises (SOES) and township and village enterprises (TVEs), thus providing large-scale employment (Bateman 2010; Loubere and Zhang 2015). It is also worth remembering that China's statedominated financial system originated in efforts to create less exploitative financial arrangements through the expulsion of local loan sharks and big capital from the financial sector after the establishment of the People's Republic of China in 1949 (Cheng 2006). Indeed, it is exactly the symbolism of the stable, non-exploitative state financial sector that Ezubao attempted to co-opt in order to deceive investors prior to the company's dramatic collapse. From this perspective, it is possible to argue, as CCTV commentator Niu Wenxin did, that online investment funds are "financial parasites" that "profit from raising economic costs for the entire society." (31)

At the core of the conceptualisation of digital financial inclusion as a driver of beneficial development is a fundamental shift in developmental thinking in China, as well as a restructuring of the relationship between the state and its citizens. In the 1980s and early 1990s, development programmes largely focussed on transferring resources to directly deal with poverty and marginalisation, particularly in the countryside. However, in 1994 microcredit became the main element in the government's flagship development strategy-the 8-7 National Poverty Reduction Programme (guojia baqi fupin gongjian jihua 国家八七扶贫攻坚计划) 一in an attempt to achieve more financially sustainable development (Tsai 2004). In this way, loans and debt replaced direct transfers of resources from the centre to the margins as a development approach. The massive industrial restructuring of China's SOEs in the late 1990s was also followed by a new microcredit programme aimed at helping the tens of millions of laid-off workers to help themselves through entrepreneurial activity (Loubere 2016). This not only had serious implications for the individuals involved by pushing them out of stable iron rice bowl employment into precarious debt-fuelled entrepreneurial activities, but also represented the abandonment of China's highly successful de-

26. Neil Gough, "Ponzi Scheme in China Gained Credibility From State Media," The New York Times, 5 February 2016, http://www.nytimes.com/2016/02/06/business/dealbook/alleged-china-ponzischeme-ezubao.html (accessed on 2 November 2017).

27. "Banking and Finance in China:The Outlook for 2015," PWC, 2015, op. cit.

28. Neil Gough, "Tops in E-Commerce, Alibaba Is Now Taking On China's Banks," The New York Times, 18 September 2014, https://dealbook.nytimes.com/2014/09/18/tops-in-e-commerce-alibabais-now-taking-on-chinas-banks/ (accessed on 2 November 2017).

29. "Banking and Finance in China:The Outlook for 2015," PWC, 2015, op. cit.

30. Peter Cai, "Alibaba'sYuebao Gives China's Banks a Rude Awakening," The Australian, 6 March 2014, http://at.theaustralian.com.au/link/2b13e82b935177db02bf2af0e1ff7723?domain=theaustralian.com.au (accessed on 2 November 2017).

31. "Fangs Are Out After 'Vampire' Slur on Online Funds," Shenzhen Daily, 25 February 2014, http://szdaily.sznews.com/html/2014-02/25/content_2787119.htm (accessed on 6 July 2017). 
velopment strategy based on supporting large enterprises capable of providing employment across society. As Aneel Karnani points out: "If societies are serious about helping the poorest of the poor, they should stop investing in microfinance and start supporting large, labor-intensive industries" (Karnani 2007, p. 34).

Key to this renegotiation of the provision of employment and welfare in contemporary China is a neoliberal pushing-off of responsibility from the state to the mythical individual entrepreneur. Financial inclusion implies that the state and other development actors are no longer responsible for providing developmental outcomes. Instead, they are responsible for providing developmental opportunities by enabling entrepreneurship (Mader 2016b). Underpinning this is the idea that marginal people are, in some ways, responsible for their own impoverishment due to the fact that they tend to make worse economic decisions than non-marginal people (World Bank 2015). (32) Increased access to financial services-often paired with financial literacy training-is therefore seen as providing them with the opportunity to make better decisions going forward. In this way, financial inclusion should not be seen as primarily inducing bottom-up socioeconomic development, as its proponents suggest. Rather, it serves to relocate the locus of developmental responsibility to the poor themselves, thereby de-linking the condition of marginality from its historical and contextual roots. This means that "the poor can once more rather neatly be blamed for their own poverty" (Bateman 2015, pp. 16-17), releasing the nonmarginal from any obligation other than identifying ways to include marginal areas and people into the economy-at a profit, of course. This mirrors shifts in Chinese developmental thinking, away from a paternalistic state-led approach and towards a focus on self-sufficiency through "humanistic modernisation" (rende xiandaihua 人的现代化) and the promotion of a "sharing economy" that will allow people to help each other, and help themselves, through increased entrepreneurialism (Loubere 2016). ${ }^{(33)}$

\section{Inclusive surveillance}

Proponents of the financial inclusion narrative depict this shift of responsibility to the individual as an inherently democratic expansion of freedom. However, if we carefully examine the promises of increased access to financial services and resources, it becomes clear that it only entails a specific type of freedom - the freedom to engage in entrepreneurial and consumer activities within the neoliberal economic system. It also becomes evident that this freedom has the potential to substantially erode or constrain other types of freedom-particularly in the digital sphere.

In the case of China, the government's support for the booming Internet finance industry, and its promotion of financial inclusion more generally, is explicitly linked to a wider project of socially engineering a "more civilised" nation through the improvement of the natural, psychological, and social "quality" (suzhi 素质) of its citizens (Barmé and Goldkorn 2013). A key component of this civilisation project is the construction of a nationwide social credit system (geren chengxin tixi 个人诚信体系) aimed at "building an environment of trust" in society. ${ }^{(34)}$ The proposed system would gather personal data and issue citizens and businesses with scores based on their economic and social activities, thereby incentivising good behaviour by "providing the trustworthy with benefits and disciplining the untrustworthy," and "letting integrity become a widespread social value." (35) In this way trustworthiness (shouxin 守信) and integrity (chengxin 诚信) are explicitly linked to financial creditworthiness (xinyong 信用). Similar to most
Chinese policy proposals, the central government is vague with regard to how credit scores will be arrived at, or what the exact consequences of having a good or bad score would be. However, a set of opinions put forward by the Central Committee and the State Council does contain suggestions for types of punishments for the untrustworthy (i.e., those with low scores), such as restrictions on access to credit, acts of conspicuous consumption, and certain types of employment, as well as ineligibility for titles such as "civilised household" (wenming jiating 文明家庭) (Loubere 2017). ${ }^{(36)}$

More than 30 prefecture-level governments around the country are already piloting various social credit systems. Interestingly, the central government has also licenced eight Internet companies to run their own pilots using data collected voluntarily (for now) from their users. The most well-known example of this is Sesame Credit, run by Ant Financial (part of the Alibaba Group). Sesame Credit uses the online consumer data generated by Alipay, which controls an $80 \%$ share of the online payment market in China. This allows Sesame Credit to calculate credit scores using opaque algorithms that take into account various aspects of shopping behaviour, with the obvious implication being that more consumption through Alipay results in higher scores. This system is already in operation, and Sesame Credit has partnered with a range of businesses that have agreed to use the scores as the basis for providing certain perks, such as access to expedited check-in at airports. ${ }^{37)}$ While modelling and piloting by local governments is a regular part of the Chinese policy process, this case is unusual as it involves private companies developing a policy model as part of their commercial business. This raises questions with regard to how (and if) public and private social credit systems will eventually be consolidated into a single nationwide system controlled by the partystate.

Chinese proponents of financial inclusion see the establishment of the social credit system as a key strategy for reducing risk for lenders and making a broadly inclusive financial system more sustainable. In Chinese policy discourse, social credit and financial inclusion are also linked (Bai 2014). (38) Internationally, however, China's proposed social credit system is nearly universally vilified as peak Orwellianism by the same people and groups who laud financial inclusion initiatives that seek to collect and op-

32. "Poor Behaviour," The Economist, 4 December 2014, https://www.economist.com/news/financeand-economics/21635477-behavioural-economics-meets-development-policy-poor-behaviour (accessed on 2 November 2017).

33. National Development and Reform Commission, "Guanyu cujin fenxiang jingji fazhan de zhidaoxing yijian de tongzhi" (Guiding opinions on promoting the development of the sharing economy), 3 July 2017, http://www.chinatax.gov.cn/n810341/n810755/c2692736/content.html (accessed on 2 November 2017)

34. For up-to-date information on the social credit system see: http://china-social-credit.com/about/ (accessed on 2 November 2017).

35. General Office of the State Council, "Guowuyuan bangongting guanyu jiaqiang geren chengxin tixi jianshe de zhidao yijian" (The General Office of the State Council's guiding opinion on the strengthening of the establishment of the personal creditworthiness system), 23 December 2016, http://www.gov.cn/zhengce/content/2016-12/30/content_5154830.htm (accessed on 2 November 2017)

36. Central Committee, and State Council, "Guanyu jiakuai tuijin shixin bei zhixing ren xinyong jiandu, jingshi he chengjie jizhi jianshe de yijian" (Opinions concerning accelerating the construction of credit supervision, warning and punishment mechanisms for persons subject to enforcement for trust-breaking), 25 September 2016, http://news.xinhuanet.com/politics/2016-09/25/c 1119620719.htm (accessed on 2 November 2017).

37. Shazeda Ahmed, "China's Social Credit System: Black Mirror or Red Herring?", China Digital Times (CDT) (blog), 16 February 2017, http://chinadigitaltimes.net/2017/02/qa-shazeda-ahmed-onchinas-social-credit-system/ (accessed on 2 November 2017); Simon Denyer, "China's Plan to Organize Its Society Relies on 'Big Data' to Rate Everyone," The Washington Post, 22 October 2016, http://www.independent.co.uk/news/world/asia/china-surveillance-big-data-score-censorship-a7375221.html (accessed on 2 November 2017).

38. Shazeda Ahmed, "China's Social Credit System: Black Mirror or Red Herring?", op. cit. 
erationalise data in similar ways. After the release of the 2016 Opinions by the Central Committee and State Council, The Economist published two high-profile articles accusing the Chinese government of inventing "digital totalitarianism" and decrying "China's worrying experiments with a new form of social control." (39) Ironically, just two months earlier they ran an article praising the potential of psychometrics (i.e. invasive personality tests) and big data to revolutionise lending — seemingly looking forward to:

a future in which lending is almost entirely digitised, combining psychometrics with social media and mobile phone records (...). Lenders, looking for an edge, will find ever more ways to peer into their customers' souls. ${ }^{(40)}$

The magazine has also praised the financial inclusion project more generally, stating: "The benefits of bringing more of the world's 2.5 billion unbanked into the formal financial system would be enormous." (41)

This illustrates that many proponents of financial inclusion seemingly have no problem with personal data being mined and used to make financial profiles of potential borrowers, just as long as governments are not involved. It also exposes a central contradiction built into the foundations of the concept of financial inclusion itself, but one that is nevertheless glossed over or ignored: inclusion into the financial system supposedly empowers and increases freedom, but in order to demonstrate creditworthiness, prospective borrowers must voluntarily provide personal information that can then be used to mould behaviour and severely restrict freedom. Indeed, prominent institutions such as the GPFI seamlessly move from discussing issues of consumer privacy to highlighting the importance of data sharing in order to reduce a variety of risks. ${ }^{(42)}$ Moreover, while financial inclusion purports to be customer focussed, better collection and use of big data is frequently held up as a means of allowing lenders to better determine the creditworthiness of potential clients under the guise of tailoring services to meet their repayment capacity. ${ }^{(43)}$ Involuntary inclusion into an Orwellian social credit system is therefore the logical end point of the commercialised digital financial inclusion project that seeks to maximise profit and minimise risk. This may increase certain freedoms for those willing and able to work within the China's increasingly neoliberal socioeconomic system—such as the adept individual entrepreneur or the happy (and wealthy) consumer. However, it undoubtedly reduces the freedoms of people who are unwilling or unable to participate, and serves to restrict the space available for contesting the dominant socioeconomic order. All of this suggests that, rather than increasing empowerment and freedom for China's poor and exploited citizens, "digital financial inclusion, if fulfilled, would immensely empower whoever controls the new monetary infrastructures" (Mader 2016a, p. 78). ${ }^{(44)}$

\section{Conclusion}

This article has examined the expansion of digital financial inclusion stemming from the rapid development of China's Internet finance industry. It outlines how the Internet finance boom has been framed within the discourse and practice of the global financial inclusion movement, which depicts the increased provision of financial services to previously excluded populations as being inherently beneficial for individual empowerment and freedom, as well as driving bottom-up development. The article then goes on to extend a conceptual critique of digital financial inclusion in China by demonstrating the ways in which these benefits have the potential to be manifested as tyrannies-producing new forms of disempowerment, undermining the potential for more equitably shared development, and limiting freedom by strengthening the capacity of the state and other powerful economic actors to exert societal control.

In particular, the article examines the example of P2P lenders exploiting university students by requiring nude photos as collateral; the widespread fraud and extraction of resources perpetuated by P2P platforms and online investment funds; and the establishment of social credit systems aimed at heightening the surveillance capacity of the Chinese party-state in coordination with Chinese Internet giants such as Alibaba. Undoubtedly, a betterdesigned regulatory framework would go a long way to reducing some of the most audacious excesses described in this article. Nevertheless, the examples are representative of processes that are fundamental to the expansion of the profit-oriented financial system, not outliers that can be willed away with technocratic tweaks. In the words of Jedediah Purdy (2014):

Even the banker with a humanitarian conscience will ultimately behave like the greediest scrooge because banking is not a posture of the spirit but a role in an economic order. If you depart from the role, the system's many representatives, playing their respective roles, will find another banker.

Indeed, the same types of destructive outcomes can be seen in more established (and supposedly better regulated) financial industries. For example, the financial inclusion provided by payday lenders in the United States serves to actively push the working poor into a state of permanent indebtedness (Hembruff and Soederberg 2015). Large-scale fraudulent behaviour perpetrated by major financial institutions was the impetus for the 2008 global financial crisis, which resulted in huge amounts of wealth being funnelled from the lower and middle classes to the "one percent" (Harvey 2014). Finally, systems of social surveillance-controlled both by governments and private corporations-have been rapidly expanding across the world, and their convergence with the financial system is simply the logical conclusion of these global trends.

These examples point to the fact that while inclusion into the profitoriented commercial financial system may produce beneficial outcomes

39. "China Invents the Digital Totalitarian State," The Economist, 17 December 2016, http://www.economist.com/news/briefing/21711902-worrying-implications-its-social-creditproject-china-invents-digital-totalitarian (accessed on 2 November 2017); "China's Digital Dictatorship," The Economist, 17 December 2016, http://www.economist.com/news/ leaders/21711904-worrying-experiments-new-form-social-control-chinas-digital-dictatorship (accessed on 2 November 2017).

40. "Test of Character," The Economist, 29 September 2016, https://www.economist.com/news/finance-and-economics/21707978-how-personality-testing-could-help-financial-inclusion-testscharacter (accessed on 2 November 2017).

41. "A Phoneful of Dollars," The Economist, 13 November 2014, https://www.economist.com/ news/briefing/21632441-worlds-poor-need-stability-and-security-banks-have-traditionally-offered (accessed on 2 November 2017).

42. "Global Standard-Setting Bodies and Financial Inclusion - The Evolving Landscape," Global Partnership for Financial Inclusion (White Paper), 2016, http://www.gpfi.org/publications/global-standard-setting-bodies-and-financial-inclusion-evolving-landscape (accessed on 2 November 2017).

43. Timothy Lyman and Kate Lauer, "What Is Digital Financial Inclusion and Why Does It Matter?", CGAP (blog), 10 March 2015, http://www.cgap.org/blog/what-digital-financial-inclusion-andwhy-does-it-matter (accessed on 2 November 2017).

44. In many ways, this mirrors the processes unleashed by China's opening and reform, and integration into the global capitalist system, which was depicted as inevitably pushing the country into a liberal (and free) democracy, but ended up arguably empowering the Party-state and its new allies in the global capitalist class, silencing alternative developmental and political discourses (Tomba 2014; Tsai 2015). 
for some individuals and groups, it also serves to reproduce highly unequal and exploitative developmental relations. They also suggest another important issue at the core of the financial inclusion discourse, but one that is not openly acknowledged by its proponents: integration into the formal financial and economic systems is not really voluntary. Once the inclusive financial infrastructure is available, it dominates and shapes socioeconomic existence in ways that make the use of newly accessible commercial financial services essentially unavoidable. In this sense, inclusion is a transformational proposition requiring the newly included to forsake traditional informal modes of financial organisation and adopt new forms of financial literacy and consciousness. This domination of the financial landscape by a digital commercial operators also shuts down spaces for alternative modes of financial organisation, such as cooperative models, that

\section{REFERENCES}

ALBRECHT, Chad, Victor MORALES, Jack Kristian BALDWIN, and Steven Deron SCOTT. 2017. "Ezubao: A Chinese Ponzi Scheme with a Twist." Journal of Financial Crime 24(2): 256-59. https://doi.org/10.1108/JFC-04-2016-0026.

ARNER, Douglas W., Janos BARBERIS, and Ross p. BUCKLEY. 2015. "The Evolution of FinTech: A New Post-Crisis Paradigm." Georgetown Journal of International Law 47: $1271-1319$.

BAl, Chengyu. 2014. "Promote the Financial Inclusion in the 'Double Dual Financial Sectors' of China." In Asia Microfinance Forum 2014. Shanghai, China.

BARMÉ, Geremie R., and Jeremy GOLDKORN (eds). 2013. Civilising China: China Story Yearbook 2013. Canberra: ANU Press.

BATEMAN, Milford. 2007. "Financial Cooperatives for Sustainable Local Economic and Social Development." Small Enterprise Development 18(1): 37-49.

-2010. Why Doesn't Microfinance Work? The Destructive Rise of Local Neoliberalism. London: Zed Books.

. 2014. "South Africa's Post-Apartheid Microcredit-Driven Calamity: Comparing 'Developmental' to 'Anti-Developmental' Local Financial Models." 47. Österreichische Forschungsstiftung für Internationale Entwicklung. http://www.econ stor.eu/handle/10419/98815.

. 2015. "Introduction." Forum for Social Economics. 1-20. https://doi.org/ 10.1080/07360932.2015.1056201.

CHENG, Yuk-shing. 2006. "China's Reform of Rural Credit Cooperatives: Progress and Limitations." Chinese Economy 39(August): 25-40.

DEER, Luke, Jackson MI, and Yuxun YU. 2015. "The Rise of Peer-to-Peer Lending in China: An Overview and Survey Case Study." Association of Chartered Certified Accountants.

DUVENDACK, Maren, Richard PALMER-JONES, James G. COPESTAKE, Lee HOOPER, Yoon LOKE, and Nitya RAO. 2011. "What Is the Evidence of the Impact of Microfinance on the Well-Being of Poor People?" London: EPPI-Centre, Social Science Research Unit, Institute of Education, University of London. http://opus.bath.ac.uk/26940/1/Microfinance_2011Duvendack_report.pdf (accessed on 1 December 2017).

GUÉRIN, Isabelle, Marc LABIE, and Jean-Michel SERVET (eds.). 2015. The Crises of Microcredit. London: Zed Books.

GUÉRIN, Isabelle, Solène MORVANT-ROUX, and Magdalena VILLARREAL. 2014 Microfinance, Debt and Over-Indebtedness: Juggling with Money. London and New York: Routledge. have the potential to be less exploitative and extractive than the commercial financial system (Bateman 2007). Future research should focus on digital inclusion as an act of transformation, and attempt to trace the impact that integration into the commercial financial system has on the social, cultural, economic, and moral worlds of newly included individuals and groups.

Nicholas Loubere is Associate Senior Lecturer in the Centre for East and South-East Asian Studies, Lund University.

Lund University, Centre for East and South-East Asian Studies,

Sölvegatan 18, 22362 Lund, Sweden (ndloubere@gmail.com).

Manuscript received on 13 July 2017. Accepted on 1 November 2017.

GUO, Feng, Sherry Tao KONG, and jingyi WANG. 2016. "General Patterns and Regional Disparity of Internet Finance Development in China: Evidence from the Peking University Internet Finance Development Index." China Economic Journal 9(3): 253-71. https://doi.org/10.1080/17538963.2016.1211383.

HARVEY, David. 2007. A Brief History of Neoliberalism. Oxford: Oxford University Press.

2014. Seventeen Contradictions and the End of Capitalism. Oxford: Oxford University Press.

HELMS, Brigit. 2006. Access for All: Building Inclusive Financial Systems. Washington D.C.:World Bank Publications.

HEMBRUFF, Jesse, and Susanne SOEDERBERG. 2015. "Debtfarism and the Violence of Financial Inclusion: The Case of the Payday Lending Industry." Forum for Social Economics: 1-20. https://doi.org/10.1080/07360932.2015.1056205.

IFAD (International Fund for Agricultural Development). 2001. "Rural Financial Services in China: Thematic Study." Report 1147-CN Rev.1.

JAMES, Deborah. 2014. Money from Nothing: Indebtedness and Aspiration in South Africa. Stanford: Stanford University Press.

JINGU, Takeshi. 2016. "China Set to Step Up Regulation of Internet Finance from 2016." lakyara 235. Beijing: Nomura Research Institute.

KARNANI, Aneel. 2007. "Microfinance Misses Its Mark." Stanford Social Innovation Review, Summer 2007: 34-40.

LOUBERE, Nicholas. 2016. "Indebted to Development: Microcredit as (De)marginalisation in Rural China." Journal of Peasant Studies. https://doi.org/10.1080/ 03066150.2016.1236025.

2017. "Cyber Loan Sharks, Social Credit, and New Frontiers of Digital Control." In Jane Colley, Linda Jaivin, and Luigi Tomba (eds.), China Story Yearbook 2016: Control. Canberra: ANU Press. 213-23.

LOUBERE, Nicholas, and Heather Xiaoquan ZHANG. 2015. "Co-Operative Financial Institutions and Local Development in China." Journal of Co-Operative Organization and Management 3(1): 32-39.

MADER, Philip. 2015. The Political Economy of Microfinance: Financializing Poverty. New York: Palgrave Macmillan.

2016a. "Card Crusaders, Cash Infidels and the Holy Grails of Digital Financial Inclusion." Behemoth - A Journal on Civilisation 9(2): 59-81. https://doi.org/10.6094/behemoth.2016.9.2.916.

2016b. "Questioning Three Fundamental Assumptions in Financial Inclusion." IDS Evidence Report 176. http://opendocs.ids.ac.uk/opendocs/ handle/123456789/9566. 
MADER, Philip, and Sophia SABROW. 2015. "All Myth and Ceremony? Examining the Causes and Logic of the Mission Shift in Microfinance from Microenterprise Credit to Financial Inclusion." Forum for Social Economics: 1-27. https://doi.org/10.1080/07360932.2015.1056204.

MORDUCH, Jonathan. 2008. "The Microfinance Schism." In David Hulme and Thankom Arun (eds.), Microfinance: A Reader. London and New York: Routledge. 17-35.

OECD. 2003. Rural Finance and Credit Infrastructure in China. Paris: OECD Publishing.

ONG, Lynette. 2012. Prosper or Perish: Credit and Fiscal Systems in Rural China. Ithaca and London: Cornell University Press.

PARK, Albert, and Changqing REN. 2001. "Microfinance with Chinese Characteristics." World Development 29(1): 39-62.

PURDY, Jedediah. 2014. "The Accidental Neoliberal." $n+1$ (19). https://nplusonemag.com/issue-19/politics/the-accidental-neoliberal/.

ROBINSON, Marguerite S. 2008. "Supply and Demand in Microfinance: The Case for a Financial Systems Approach." In David Hulme and Thankom Arun (eds), Microfinance: A Reader. London and New York: Routledge. 45-64.

RUTHERFORD, Stuart. 2006. "Grameen II:The First Five Years 2001-2005." Dhaka, Bangladesh: MicroSave. http://www.cgdev.org/doc/blog/Rutherford,\%20Gra meen\%20ll-The\%20First\%20Five\%20Years,\%202001-2005.pdf (accessed on 7 April 2013)

SPARREBOOM, Pete, and Eric DUFLOS. 2012. "Financial Inclusion in China." China Papers on Inclusiveness (7). Consultative Group to Assist the Poor.
http://www.cgap.org/sites/default/files/CGAP-WMFG-Financial-Inclusion-inChina-Aug-2012.pdf (accessed on 1 December 2017)

TAYLOR, Marcus. 2011. "'Freedom from Poverty Is Not for Free': Rural Development and the Microfinance Crisis in Andhra Pradesh, India." Journal of Agrarian Change 11(4): 484-504.

2012. "The Antinomies of 'Financial Inclusion': Debt, Distress and the Workings of Indian Microfinance." Journal of Agrarian Change 12(4): 601-610.

TOMBA, Luigi. 2014. The Government Next Door: Neighborhood Politics in Urban China. Ithaca: Cornell University Press.

TSAI, Kellee S. 2004. "Imperfect Substitutes: The Local Political Economy of Informal Finance and Microfinance in Rural China and India." World Development 32(9): 1487-1507.

2015. Capitalism without Democracy: The Private Sector in Contemporary China. Ithaca and London: Cornell University Press.

WEBER, Heloise. 2004. "The 'New Economy' and Social Risk: Banking on the Poor?" Review of International Political Economy 11(April): 356-86.

World Bank. 2014. Global Financial Development Report 2014: Financial Inclusion. Washington D.C.:The World Bank.

2015. World Development Report 2015: Mind, Society, and Behavior. Washington D.C.:The World Bank.

YUNUS, Muhammad, and Karl WEBER. 2007. Creating a World Without Poverty: Social Business and the Future of Capitalism. New York: PublicAffairs. 